\title{
Akademickie Towarzystwo Andragogiczne - ciągłość i zmiana
}

\author{
Academic Andragogic Society - continuity and change
}

Streszczenie. W artykule dokonano analizy aktualnych warunków funkcjonowania Akademickiego Towarzystwa Andragogicznego. Wskazano wyzwania, przed jakimi stoi towarzystwo, oraz podjęto próbę wskazania współczesnej roli Akademickiego Towarzystwa Andragogicznego w świecie permanentnej zmiany. Za fundament działalności organizacji uznano balans pomiędzy ciągłością i zmianą.

Kluczowe słowa: Akademickie Towarzystwo Andragogiczne, wyzwania, ciągłość, zmiana

Summary. In the article the current working conditions of Academic Andragogic Society have been analysed. The challenges of the association were pointed out and there was an attempt to indicate the present role of the Academic Andragogy Association in the world of permanent change. A balance between continuity and change was considered to be the foundation of the organisation's activity.

Key words: Academic Andragogic Society, challenges, continuity change

Akademickie Towarzystwo Andragogiczne jest stowarzyszeniem społecznym, które działa na rzecz wspierania aktywności naukowo-badawczej polskich andragogów oraz współpracuje ze środowiskiem instytucji i osób angażujących się w działania w obszarze formalnej, pozaformalnej i nieformalnej edukacji dorosłych. Promując ideę uczenia się przez całe życie, ATA inicjuje szereg przedsięwzięć, których podstawą jest dialog prowadzony z partnerami w kraju i za granicą. Celem działań ATA jest aktywny udział w konstruowaniu wspólnego obszaru wiedzy o edukacji dorosłych, dbanie o wysoki poziom przekazu wiedzy na temat uczenia się dorosłych, budowanie prestiżu teorii i praktyki edukacji dorosłych w opinii publicznej, tworzenie płaszczyzn współpracy pomiędzy akademikami i praktykami, w tym ze świata 
kultury, biznesu i organizacji pozarządowych. Do podstawowych form działalności Akademickiego Towarzystwa Andragogicznego należy:

- organizowanie zjazdów andragogicznych i cyklicznych konferencji andragogicznych,

- prowadzenie działalności wydawniczej,

- przyznawanie nagród za wybitne monografie,

- udzielanie patronatu nad przedsięwzięciami, które służą teorii i praktyce edukacji dorosłych,

- współpraca z innymi podmiotami na rzecz teorii i praktyki edukacji dorosłych (www.ata.edu.pl/misja.html).

25 lat Akademickiego Towarzystwa Andragogicznego to dobra okazja, by dokonać nie tylko analizy przeszłości, ale także zastanowić się nad aktualnym warunkami funkcjonowania towarzystwa i jego współczesnym znaczeniem.

Żyjemy w czasach permanentnej zmiany we wszystkich dziedzinach życia. Tym bardziej pogłębiony namysł nad zmianą, a szczególnie jej pożądanymi i niepożądanymi skutkami, podnosi wagę stałego monitorowania $\mathrm{i}$ interpretowania zmian $\mathrm{w}$ sferze teorii oraz reagowania na nie lub ich ignorowania w sferze praktyki. Innym mechanizmem rządzącym kulturą jest ciągłość, która pozwala na przekaz tradycji, kontynuowanie dzieła poprzedników. Mimo presji nowoczesności myślenie w kategoriach historycznych ciągłości i zmiany - odgrywa dziś dużą rolę w naukach społecznych. Także dla Akademickiego Towarzystwa Andragogicznego - ciągłość i zmiana - są fundamentem filozofii działania.

Jakie współcześnie znaczenia niosą ze sobą pojęcia tworzące nazwę naszego Towarzystwa, jaką rolę odgrywa w nich ciągłość i zmiana, przed jakimi wyzwaniami stoimy?

Pojęcie „akademickie” - odnosi się do pierwotnego znaczenia akademii, tj. zgromadzenia uczonych. Dalej przenosi naszą uwagę na szkolnictwo wyższe, które przechodzi od 1989 r. kolejne, nakładające się na siebie i w rezultacie niedokończone reformy. Aktualnie jesteśmy w trakcie oczekiwania na tzw. Konstytucję dla nauki, która zakłada daleko idące zmiany dotyczące finansowania i zarządzania uczelni, ścieżek awansu, nowej klasyfikacji dziedzin i dyscyplin naukowych, większego pola do interdyscyplinarnych badań i dydaktyki. Celem reformy jest wzmocnienie potencjału polskiej nauki w międzynarodowym kontekście. To oznacza większy nacisk na badania stosowane, przełomowe, interdyscyplinarne, możliwe jedynie jako efekt pracy zespołu uczonych. W obliczu takich priorytetów nauki społeczne i humanistyczne są w trudnym położeniu, a rola uczonych tych dziedzin 
nauki, szczególnie w Polsce, jest niedoceniana. Co oferuje w opisanej skrótowo sytuacji Akademickie Towarzystwo Andragogiczne swoim członkom? ATA jest stałym punktem odniesienia, rusztowaniem dla zawodowej tożsamości, miejscem doskonalenia zawodowego oraz doradztwa naukowego w sytuacji niepewnych, realizowanych pod presją czasu, przerywanych karier naukowych i mozaikowych karier zawodowych. Stanowimy także niezależną od uczelni organizację, którą tworzą pracownicy naukowi różnych generacji, wspierający się wzajemnie w budowaniu naukowego profesjonalizmu w dziedzinie andragogiki. Prowadzimy własną działalność wydawniczą publikacji naukowych, organizujemy własne naukowe wydarzenia, patronujemy wydarzeniom andragogicznym innych podmiotów, gwarantując akademicką jakość. Aby wzmocnić realizację przedsięwzięć naukowo-badawczych, Akademickie Towarzystwo Andragogiczne weszło w skład Konsorcjum Lifelong Learning, które zakłada realizację takich zadań jak: prowadzenie i promocja wspólnych prac badawczych, dydaktycznych, rozwojowych, wymiana wyników badań oraz doświadczeń dydaktycznych, wsparcie naukowe i metodyczne w rozwoju wysoko kwalifikowanej kadry naukowej i naukowo-dydaktycznej, podejmowanie wspólnych przedsięwzięć publikacyjnych, współpraca $z$ innymi podmiotami zajmującymi się działalnością naukową, badawczą, edukacyjną. Prowadzimy rozmowy z Instytutem Badań Edukacyjnych, aby Konsorcjum mogło włączyć się w badania i ekspertyzy dotyczące polityki i praktyki oświatowej w obszarze edukacji całożyciowej.

Towarzystwo - towarzystwa naukowe, do których zalicza się ATA, mają w naszym kraju swoje długie i piękne tradycje. Przez długi okres historii Polski były wyrazem dążeń demokratycznych naszego społeczeństwa, podyktowanych wolą uzyskania choćby pewnej niezależności wobec głównego nurtu politycznego (więcej na ten temat: Maliszewski 2018, w niniejszym tomie). W zmienionych warunkach społeczno-politycznych towarzystwa naukowe nie pełnią już tak doniosłej roli jak w przeszłości, nawet traktowane są jako „relikt minionych epok, w związku z czym nie powinny być przedmiotem opieki ze strony państwa, lecz funkcjonować jedynie zgodnie z prawami rynku" (Kruszewski 2008, s. 9). To stawia towarzystwa naukowe w trudnej finansowo sytuacji i powoduje, że działalność ATA zmuszeni jesteśmy finansować zasadniczo ze składek członków. Budowaniu członkostwa nie sprzyja system zatrudniania i awansu zawodowego w szkolnictwie wyższym, w którym nie ma już etapu przygotowywania i wdrażania do pracy naukowej w roli asystenta pod opieką mentora. W sprawozdaniach z działalności naukowej docenia się dziś jedynie członkostwo we władzach zagranicznych lub międzynarodowych organizacji, towarzystw, instytucji naukowych. 
Świat wirtualny zapewnił także wiele form i możliwości informowania, komunikowania i zrzeszenia się - tworzenia otwartych i zamkniętych oraz niezobowiązujących grup, blogów, sieci, klastrów. Otrzymujemy współcześnie spersonalizowaną ofertę udziału w świecie wirtualnym, który już nierozerwalnie łączy się z naszym realnym światem zawodowym. Skutkiem ubocznym jest już nie tyle nadmiar informacji, co tymczasowość wiedzy, przygodność kontaktów, okazjonalność i nietrwałość. Co wobec powyższego oferuje Akademickie Towarzystwo Andragogiczne? Zaspakaja potrzebę przynależności w szerszym tego słowa znaczeniu, gwarantuje osobisty kontakt, umożliwia niezapośredniczony dialog, daje szansę na stabilność w niestabilnym życiu zawodowym. Towarzystwo jest także środowiskiem, w którym znaleźć można szacunek i uznanie, dlatego odnotowujemy awanse naukowe, pamiętamy o jubileuszach, wyróżniamy nagrodą ATA wybitne monografie, podejmujemy starania o uznanie naszych członków w innych gremiach. Stanowimy dla siebie wsparcie w trudnych momentach życia zawodowego, na co nie zawsze można liczyć w środowisku pracy, w którym dużą rolę odgrywa rywalizacja. Nowoczesne media i komunikatory umożliwiają bardziej niż kiedyś pielęgnowanie relacji międzyludzkich, współpracę w świecie rzeczywistym oraz bieżącą informację, którą zapewniamy poprzez stronę internetową ATA oraz newsletter ATA.

Andragogiczne - to pojęcie w nazwie towarzystwa wskazuje na jego specjalizację i wpływa na potencjalną i rzeczywistą liczebność jego członków. Mimo że na przestrzeni 25 lat funkcjonowania towarzystwa liczba członków podwoiła się i wynosi aktualnie 80 osób, to Akademickie Towarzystwo Andragogiczne należy do grupy małych organizacji, ale dzięki temu członkowie ATA mogą ze sobą ściślej wspólpracować. W latach 90. wierzyliśmy w dynamiczny rozwój teorii i praktyki edukacji dorosłych. Dziś musimy stwierdzić, że rola edukacji dorosłych w życiu społecznym wyrażona liczbą uczących się dorosłych jest ciągle niewielka, a edukacja całożyciowa jest raczej sloganem niż atrakcyjną, bogatą znaczeniowo formułą stosowaną w życiu codziennym. Także instytucjonalna oferta edukacji dorosłych osiągnęła status quo i nie wpływa dynamizująco na wzrost kadry naukowej i przez to także na jej siłę w środowisku naukowym. W nauce postępuje proces zanikania granic dyscyplin, rośnie znaczenie studiów oraz badań inter- i transdyscyplinarnych. Mieczysław Malewski już w 1995 r. opublikował artykuł pod znaczącym tytułem Andragogika - dyscyplina bez przedmiotu badań, wskazując na słabości przedmiotowej orientacji, gdzie „ideologiczna zdefiniowana rzeczywistość edukacyjna, awansowana do roli przedmiotu badań andragogiki, zamyka jej rozwój w obrębie pojęciowych granic zakreślonych przez 
tę definicję" (ibidem, s. 144). Rozwój teorii edukacji dorosłych, który jest współcześnie naszym udziałem, wynika z pojmowania pola badawczego jako obszaru złożonego z pytań i problemów, które wynikają z konceptualnej wizji przedmiotu badań, dającej badaczom dużą swobodę w stawianiu pytań oraz w doborze teorii i metodologii, by udzielić na nie odpowiedzi (Tamże, s. 147-148). O rozwoju andragogiki jako nauki o edukacyjnym wspomaganiu człowieka dorosłego zdecyduje teoretyczna płodność stawianych pytań, dojrzałość metodologiczna, refleksyjność badaczy, a także zbiorowy wysiłek środowiska wyznaczającego wysokie standardy pracy naukowej. Jaką rolę w omawianym obszarze może pełnić Akademickie Towarzystwo Andragogiczne? Powinno stać na straży wysokich standardów pracy naukowej poprzez sygnowane czasopisma i publikacje, typowane do nagród i wyróżnień osiągnięcia naukowe badaczy-andragogów, promowanie dorobku andragogów w innych środowiskach czy reprezentowanie naszego środowiska w innych gremiach, np. w Komitecie Nauk Pedagogicznych oraz za granicą. ATA ma ważną rolę do odegrania w mapowaniu dorobku andragogiki, których adresatem byłyby także inne środowiska naukowe, korzystające $z$ naszych osiągnięć, by upowszechniać współczesną interpretację teorii i praktyki edukacji dorosłych. Nieustanną troską Akademickiego Towarzystwa Andragogicznego pozostanie skupianie specjalistów edukacji dorosłych, by tworzyć warunki do naukowych sporów i organizować andragogiczny dyskurs.

Jesteśmy krytyczni, ale i dumni ze stanu i osiągnięć polskiej andragogiki po 1989 r. oraz wkładu w to dzieło Akademickiego Towarzystwa Andragogicznego. Przed nami nowe wyzwania i duża odpowiedzialność za zachowanie balansu pomiędzy ciągłością i zmianą.

\section{Bibliografia}

Kruszewski Z. (2008), Rola towarzystw naukowych w podnoszeniu poziomu wiedzy społeczeństw lokalnych, „Notatki Płockie”, 2, 2015, s. 9-13.

Kruszewski Z. (2012) Towarzystwo Naukowe Płockie - podmiot życia publicznego, PWN, Warszawa.

Malewski M. (1997), „Rocznik Andragogiczny” 1995/1996, s. 142-153.

Maliszewski T. (2018), Akademickie Towarzystwo Andragogiczne - 25 lat doświadczeń w pracy na rzecz polskiej teorii i praktyki edukacji dorostych, „Rocznik Andragogiczny", s. 28-48.

Półturzycki J. (2007), Działalność Akademickiego Towarzystwa Andragogicznego w latach 1993-2008, „Rocznik Andragogiczny”, s. 21-46. 


\section{4 | Hanna Solarczyk-Szwec}

Rolbiecki W. (1986), Towarzystwa naukowe, [w:] Encyklopedia oświaty i kultury dorosłych, red. K. Wojciechowski, Wrocław, s. 337-340.

Skibińska E. (2012), Akademickie Towarzystwo Andragogiczne - 20 lat działalności, „Rocznik Andragogiczny”, s. 79-88.

\section{Netografia}

http://www.ata.edu.pl - strona domowa Akademickiego Towarzystwa Andragogicznego [dostęp, 14.03.2018] 